Konrad BANAŚ

Uniwersytet Łódzki, Polska

\title{
Geneza i przebieg konfliktu w Czadzie 1965-1984
}

\section{Origin and Course of Conflict in Chad 1965-1984}

\section{- Abstrakt •}

Niepopularne decyzje pierwszego prezydenta Czadu Françoisa Tombalbayego szybko doprowadziły do niezadowolenia, szczególnie dyskryminowanej, muzułmańskiej ludności na północy kraju. Państwo to bowiem składa się z wielu plemion, posługujących się licznymi dialektami i wyznających: islam, chrześcijaństwo oraz animizm. Nie bez znaczenia są również sztuczne granice, jakie posiada Czad, nieodzwierciedlające ani układu etnicznego, ani kontekstu historycznego.

Wojna domowa rozpoczęla się już w 1965 r., a w roku następnym zawiązał się Front Wyzwolenia Narodowego Czadu (FROLINAT). Było to rebelianckie ugrupowanie dążące do obalenia prezydenta. Terror wewnętrzny oraz czystki w wojsku doprowadzily w 1975 r. do obalenia F. Tombalbayego i przejęcia władzy przez gen. F. Mallouma. FROLINAT kontynuował jednak walkę aż do odsunięcia prezydenta w 1979 r. przez Hissèna Habréa. Kolejne lata przypadły na długotrwałą i krwawą walkę nowego prezydenta ze swoim byłym współpracownikiem Goukounim Oueddeim. W tym czasie w sprawy Czadu ingerowała już nie tylko Francja, ale również Libia, USA oraz państwa ościenne. Zewnętrzne wsparcie dla walczących polityków powodowało przedłużanie się kryzysu czadyjskiego.

\section{- Abstract •}

Unpopular decisions of the first president of Chad, François Tombalbaye, quickly led to dissatisfaction, mainly among discriminated Muslim people living in the northern part of the country, for Chad's population comprises a number of tribes. They speak different dialects and have different religious beliefs, including Islam, Christianity, and Animism. Not without significance is also the fact that the borders of the country were set artificially, with no consideration of ethnic areas or historical context.

As soon as in 1965, a civil war erupted and in the following year the National Liberation Front of Chad (FROLINAT) was established. It was a rebel group aiming to overthrow the president. In 1975, in effect of internal terror and purge in the army, F. Tombalbaye was overthrown and succeeded by gen. F. Malloum. Yet FROLINAT continued the fight until 1979 when Hissène Habré took over. The subsequent years made the long-lasting period of bloody combat between the new president and his ex-collaborator Goukouni Oueddei. During that time, several countries started to intervene in Chadian internal affairs, including France, Libya, USA and neighboring countries. Foreign support for opposing politicians made the crisis in Chad even longer. 
Słowa kluczowe: Czad, Libia, wojna domowa w Czadzie, wojna czadyjsko-libijska, konflikty w Afryce
Keywords: Chad, Libya, civil war in Chad, Chadian-Libyan war, conflicts in Africa

Czad uzyskał niepodległość 11.08 .1960 r. jako była kolonia francuska. Jego pierwszy prezydent - François Tombalbaye - bardzo szybko wprowadził rządy dyktatorskie. Zdelegalizował wszystkie partie polityczne poza Czadyjską Partią Postępu (PPT), na czele której stał (Le problème tchadien. Rappel historique, 1984, s. 10; Jabłonowski, 1988, s. 10). Prezydent rozpoczął również forsowną afrykanizację kraju, polegającą na usuwaniu administracji, zarządców i farmerów francuskich, zastępując ich Czadyjczykami. Ci jednak nie posiadali dostatecznej wiedzy oraz umiejętności, co poskutkowało zapaścią gospodarczą państwa. Przywódca swoją władzę oparł na plemieniu Sara, z którego pochodził. Było to efektem faworyzacji chrześcijańsko-animistycznego południa kraju, co w wieloetnicznym Czadzie wywołało silny opór, szczególnie muzułmańskiej północy (Collier, 1990a, s. 17-19; Jakubowski, 1987, s. 13).

Wzajemne antagonizmy wewnątrzczadyjskie, spotęgowane przez stronnicze rządy F. Tombalbayego, spowodowały antyrządowe wystąpienia już w 1963 r., które dwa lata później przerodziły się w wojnę domową. Konflikt doprowadził de facto do podziału państwa na muzułmańską północ i chrześcijańsko-animistyczne południe. Na przestrzeni lat 60 . prezydent F. Tombalbaye stracił kontrolę nad większością miast centralnych i północnych prefektur. Muzułmańskie bojówki formowały się w ościennych, islamskich państwach i korzystały z ich pomocy. W 1966 r. kierownictwo nad działaniami północy objął, wspierany przez Sudan, Front Wyzwolenia Narodowego Czadu (FROLINAT). Działania rebeliantów nie były jednak skoordynowane, a ich sukcesy wynikały raczej z nieudolności F. Tombalbayego niż z rzeczywistej siły (Tartter, 1990, s. 188-189; Pledge, 1970, s. 97-99; Pasierbiński, 1969, s. 9).

W tłumieniu ruchów partyzanckich prezydent zwrócił się w 1968 r. o pomoc do dawnej metropolii. Wykorzystał przy tym, podpisany 15.08 .1960 r., układ pomiędzy Francją, Czadem, Kongiem-Brazzaville i Republiką Środkowoafrykańską o wzajemnej obronie (Łętocha, 1970, s. 94-97). Dawna metropolia była żywo zainteresowana utrzymaniem swoich wpływów w tak strategicznie położonym państwie jakim jest Czad. Francja wyraziła zgodę, jednak za cenę reform gospodarczych i administracyjnych, które zostały opracowane przez 33-osobową Misję Reformy Administracyjnej (MRA) złożoną z Francuzów. MRA zniosła niektóre niepopularne podatki i ustawy. Najważniejszym posunięciem Misji było jednak przywrócenie władzy sądowniczej lokalnym wodzom plemion muzułmańskich. 
Ponadto mogli oni zbierać podatki, zatrzymując dla siebie $10 \%$. Posunięcie to czasowo osłabiło działania rebeliantów.

Na przełomie lat 60. i 70. prezydent F. Tombalbaye zliberalizował swoją politykę. Zwolnił ponad 2 tys. więźniów politycznych i rozpoczął rozmowy z muzułmańskimi przywódcami rebeliantów. W czerwcu 1971 r., podczas wizyty na północy Czadu, obiecał rządowe dotacje do cen cukru i soli dla nomadów. Te poczynania spowodowały faktyczne ograniczenie rebelii do gór Tibesti oraz stopniową ewakuację wojsk francuskich (Collier, 1990a, s. 20-21; Kostecki, 1971, s. 33).

Polityka odwilży została nagle przerwana w sierpniu 1971 r. po nieudanym zamachu na F. Tombalbayego, o który ten oskarżył, niedawno amnestiowanych, rebeliantów. Ci z kolei mieli być wspierani przez nowego przywódcę Libii - Maummara Kaddafiego. W odpowiedzi prezydent Czadu zerwał stosunki dyplomatyczne z północnym sąsiadem i zaprosił do siebie libijskich opozycjonistów. W reakcji na to M. Kaddafi oficjalnie zaczął wspierać FROLINAT, organizując jego bazy na terytorium Libii oraz dostarczając broń (Moszumański, 2007, s. 114-115).

François Tombalbaye szukał zbliżenia z innymi państwami arabskimi, zrywając w 1972 r. stosunki dyplomatyczne z Izraelem, mimo że jeszcze przed dwoma laty państwo to wspomagało prezydenta Czadu, wysyłając doradców wojskowych, w zamian licząc na udostępnienie bazy wojskowej w górach Tibesti (Jackowski, 1970, s. 3). Ponadto dążył do zacieśnienia współpracy z afrykańskimi państwami francuskojęzycznymi. Na tym polu udało mu się nawiązać współpracę z Mauretanią (J.L. Corell, 1990, s. 22). Aby osłabić siły FROLINAT, prezydent w 1973 r. porozumiał się z Libią, przekazując jej tzw. Strefę Aouzou'1. W zamian M. Kaddafi wstrzymał pomoc dla muzułmańskich rebeliantów i udzielił Czadowi wsparcia gospodarczego (Buijtenhuijs, 1981, s. 29).

Strefa Aouzou stanowiła część terytorium Czadu, która przypadła temu państwu zgodnie z postanowieniami traktatu granicznego z 1955 r. między Francją a Libią. Muammar Kaddafi zgłaszał roszczenia do Strefy, powołując się na nieratyfikowany traktat z 1935 r. między Francją a Włochami, włączający wspomniany teren w obręb włoskiej Libii. Tereny te zamieszkiwane były przez ludność językowo, kulturowo oraz religijnie bardziej zbliżoną do mieszkańców Fazzanu w południowej Libii oraz Dar Furu w północno-zachodnim Sudanie niż do ludności z południowego Czadu (Le problème tchadien. Rappel historique, 1984, s. 9). Zajmując Strefę Aouzou, w dalszej perspektywie M. Kaddafi dążył do stworzenia islamskiego imperium obejmującego środkowy Sahel (Byrnes, 1990, s. 160-161). Innym czynnikiem powodującym zainteresowanie Libii wspomnianym teryto-

${ }^{1}$ Pas terytorium Czadu o szerokości około $100 \mathrm{~km}$ położony przy granicy z Libią. 
rium były złoża mineralne na tym obszarze, zwłaszcza cenna ruda uranu (Berry, 1989, s. 55).

W tym samym czasie prezydent F. Tombalbaye zintensyfikował czystki wewnątrz własnego rządu, usuwając ludzi wywodzących się z południa, w tym dwóch ministrów cieszących się dużym autorytetem wśród ludności chrześcijańsko-animistycznej. Czystki nie ominęły również PPT, gdzie oskarżał niektórych działaczy o czary. Aby zwiększyć swój autorytet wśród Czadyjczyków, F. Tombalbaye powrócił do zagadnienia afrykanizacji państwa. Obyczaje, nazwy i symbole francuskie były zastępowane tymi, które uznano za rodzime. To wówczas nazwę stolicy państwa zmieniono z Fort-Lamy na Ndżamena. Wielu urzędników zmuszano do udziału w rytuale „yondo”, polegającym na "nowych narodzinach”, w trakcie którego należało się poddać rozmaitym bolesnym zabiegom² ${ }^{2}$.

Wysiłki te na nic się zdały, gdyż prezydent dalej tracił popularność, do czego przyczyniła się kolejna wielka susza w roku $1974^{3}$. Aby rozwiązać problem żywności, F. Tombalbaye ogłosił Projekt Rolnictwo, zakładający agrarne zaktywizowanie nieuprawianych dotąd terenów. Na obszarach tych planowano uprawę bawełny, głównego produktu eksportowego Czadu. W praktyce polegało to na wysyłaniu ludności miejskiej na obszary półpustynne w celu uprawy roli, która i tak nie przyniosłaby żadnych plonów, bowiem brakowało tam wody, a mieszkańcy miast nie znali się na rolnictwie. Projekt ten obrócił się przeciwko prezydentowi, ponieważ ludność wysyłana na półpustynię pochodziła z miast południa, które dotąd popierało F. Tombalbayego (Corell, 1990, s. 23-24; Budrewicz, 1974, s. 18-21, 25; Budrewicz, 1977, s. 35-46). Przymusowa wysyłka do prac rolnych oraz czystki w wojsku i żandarmerii przechyliły szalę na niekorzyść prezydenta. Szereg niepopularnych decyzji doprowadził do puczu wojskowego i zamordowania przywódcy w dniu 13.04.1975 r. (Moszumański, 2007, s. 115-116).

Władzę w Czadzie przejęła Najwyższa Rada Wojskowa (CSM), na jej czele stanął płk. Félix Malloum. Nowa junta wojskowa wprowadziła do rządu muzułmanów, jednak przewaga pozostała po stronie południa. Prezydent F. Malloum nie zmienił zasadniczo sytuacji w kraju. Bezskutecznie próbował porozumieć się z przywódcami rebeliantów (Le problème tchadien. Rappel historique, 1984, s. 12). Pogorszyły się natomiast stosunki z Francją. Przywódca miał za złe dawnej metropolii, że za jego plecami zaczęla prowadzić negocjacje z rebeliantami w spra-

${ }^{2}$ Miasto Fort-Lamy zostało założone w 1900 r. przez Francuzów i nie miało swojej rodzimej nazwy. Dlatego F. Tombalbaye nazwał stolicę od sąsiedniej wsi Ndżamena, co oznacza „miejsce wypoczynku". Szerzej na ten temat vide: Budrewicz, 1977, s. 53-55.

${ }^{3}$ W wielu regionach susza trwała już od 1965 r.; vide: Katastrofalne skutki suszy w Afryce, 1973, s. 5; Dembiński, 1974, s. 1-2. 
wie wydania, porwanej w 1974 r., francuskiej archeolog Françoise Claustre. Prezydent Czadu w reakcji na to zażądał wycofania 1,5 tys. francuskich żołnierzy stacjonujących w Ndżamenie (Collier, 1990b, s. 24-26; Janicki, 1975, s. 3; Lubowski, 1975, s. 13) .

Do konfliktu znów włączyła się Libia, która wznowiła dostawy dla rebeliantów. Dzięki temu ci dwukrotnie oblegali Faya-Largeau w 1976 r., a w następnym roku zdobyli miasto Bardaï w górach Tibesti (Rapacki, 1978, s. 9). Sukcesy rebeliantów zostały zahamowane przez konflikt pomiędzy ich liderami: dowódcą Sił Zbrojnych Północy (FAN) Hissènem Habréem a przewodniczącym Rady Dowództwa Sił Zbrojnych Północny (CCFAN ) - Goukounim Oueddeim. Ten pierwszy był przeciwny libijskiej obecności w Strefie Aouzou. Jego oponent zaś za priorytet uważał walkę z CSM przy wykorzystaniu libijskiej pomocy. W wyniku konfliktu H. Habré musiał uciekać do Sudanu (Tartter, 1990, s. 189; Kamiński, 1987a, s. 7).

We wrześniu 1977 r. F. Maloum spotkał się w Libreville z czołowym opozycjonistą G. Oueddeim. Ten zażądał od prezydenta m.in. proporcjonalnego udziału swoich ludzi w nowym rządzie, na co nie uzyskał zgody. W obliczu fiasku rozmów F. Malloum, w grudniu 1977 r., spotkał się w Chartumie z przeciwnikiem G. Oueddeiego, a teraz byłym dowódcą wojsk rebelianckich - H. Habréem. Ten nie miał już tak wygórowanych żądań i w wyniku rokowań został mianowany premierem. W tym samym czasie została również zwolniona francuska archeolog, co w połączeniu z antyfrancuskimi hasłami G. Oueddeiego, spowodowało zintensyfikowanie poparcia dawnej metropolii dla CSM. W obliczu nowego układu sił w Czadzie wspierany przez Libię FROLINAT zajął na początku 1978 r. całą północ kraju, razem z Faya-Largeau. Nie udało się natomiast zdobyć stolicy (Buijtenhuijs, 1984, s. 17-19; Moszumański, 2007, s. 117; Rapacki, 1980, s. 9).

Sojusz F. Mallouma z H. Habréem nie przetrwał długo. Ten drugi forsował w rządzie i administracji muzułmanów z północy, co doprowadziło do rozpadu koalicji na początku 1979 r. 12.02 .1979 r. premier, przy pomocy oddanych mu jednostek FAN i bierności garnizonu francuskiego, zmusił prezydenta F. Mallouma do „przejścia na emeryturę”. Z kolei G. Oueddei, wykorzystując chaos w stolicy, 10 dni później wszedł do Ndżameny. W tym czasie rozgrywały się pogromy ludności chrześcijańskiej i animistycznej, zmuszonej do masowej emigracji z Czadu (Collier, 1990b, s. 27-28; Kamiński, 1979, s. 5).

Aby ukrócić czadyjską anarchię, od marca do sierpnia 1979 r. w Nigerii trwały rozmowy państw graniczących z Czadem na temat rozwiązania sytuacji w tym

\footnotetext{
${ }^{4}$ Szerzej na temat porwania francuskiej archeolog vide: Czekała-Mucha, 1979, passim.
} 
kraju. Ostateczne porozumienie podpisano 21.08 .1979 r. w Lagos. Widniały na nim podpisy przedstawicieli 11 czadyjskich frakcji oraz 9 państw regionu. Układ zakładał powołanie Przejściowego Rządu Jedności Narodowej (GUNT). Jego przewodniczącym, a de facto prezydentem, został G. Oueddei. Natomiast H. Habré został ministrem obrony, kombatantów i ofiar wojny (Gérard, 1984, s. 120; Angoyo, 1986, s. 103; Kalabiński, 1980, s. 13).

Konflikty osobiste pomiędzy członkami rządu, zwłaszcza pomiędzy dawnymi sojusznikami: G. Oueddeim i H. Habréem, ograniczały efektywność władzy, w efekcie czego już 20.03.1980 r. znów wybuchły walki (Kamiński, 1979, s. 5). Prezydent w praktyce nie kontrolował stolicy. Pragnąc zmienić ten stan rzeczy, ponownie sprzymierzył się z Libią 15.06 .1980 r. Zgodnie z tym porozumieniem, G. Oueddei miał prawo wezwać pomocy M. Kaddafiego, gdyby integralność Czadu została naruszona. Wykorzystując ten punkt, prezydent - wraz z pomocą 7-9 tys. żołnierzy libijskich oraz radzieckich i enerdowskich instruktorów wojskowych - zajął w dniach 8-15 grudnia stolicę i inne miasta południa. Współpracująca z G. Oueddeim Demokratyczna Rada Rewolucyjna (CDR) zmusiła H. Habré’a do wycofania się do prefektury Biltine przy granicy z Sudanem (Tartter, 1989, s. 248-250).

W praktyce G. Oueddei stał się marionetką M. Kaddafiego, który nawet podpisał 6.01.1981 r. plan zjednoczenia obu państw. Projekt spotkał się z ostrą krytyką Francji, państw Organizacji Jedności Afrykańskiej oraz licznych ugrupowań wewnątrz kraju. Ataki czadyjskich partyzantów oraz presja międzynarodowa zmusiły wojska libijskie do opuszczenia większości terytorium Czadu, pozostając jednak w Strefie Aouzou (Berry, 1989, s. 55-56; Jedna Dżamahirijja? 1981, s. 12-13). $\mathrm{Z}$ inicjatywy OJA zostały one zastąpione przez siły pokojowe Inter-African Force (IAF) złożone z 2 tys. żołnierzy nigeryjskich, tyleż samo zairskich oraz 800 senegalskich. Misja IAF w Czadzie miała być finansowana przez siedem państw afrykańskich, lecz szybko wyniknęły nieporozumienia na tym polu, w efekcie czego IAF unikał walk (Tartter, 1990, s. 191-192).

Polska prasa bezapelacyjne sprzyjała stanowisku Libii. Miesięcznik „As Sadaka" - polskojęzyczny oficjalny organ Towarzystwa Przyjaźni Libijsko Arabsko-Polskiej, stał na stanowisku, że wojska Dżamahiriji znalazły się w Czadzie wskutek prośby legalnych władz, z G. Oueddeim na czele, w celu przeciwstawienia się , ,... [ zagrożeniu niepodległości państwa, wojny domowej, wywołanej knowaniami kolonialistów, którzy chcieli podporządkować sobie ponownie niepodległy Czad”. Ich ewakuacja zaś odbyła się również na prośbę G. Oueddeiego. Nie wspomniano ani słowem o libijskich porażkach i presji międzynarodowej. Krytycznie odnoszono się również do misji IAF. Jednostki te miały być narzędziem Francji, 
co czyniło je stronniczymi. W ten sposób tłumaczono bierność afrykańskich sił w konflikcie domowym w Czadzie (Pogodowski, 1982, s. 61; Radajewicz, 1982, s. 61; Kamiński, 1986, s. 5).

Nie tylko czasopismo „As Sadaka” było skrajnie nieobiektywnie. Wiele do życzenia pozostawał poziom rzetelności innych polskojęzycznych tytułów. Najczęściej można było spotkać się z prolibijskim stanowiskiem, pozytywnie oceniającym interwencję M. Kaddafiego w Czadzie. Podczas prób przedstawienia sytuacji wewnętrznej w tym państwie H. Habré jest postacią negatywną, współpracującą z dawnymi kolonistami i „imperialistami” z USA. Zupełnie inaczej kreowana była postać G. Oueddeiego. Mimo że nie było ku temu podstaw, ani nie podawano żadnych argumentów, przywódca GUNT kreowany był na męża stanu, pragnącego wyzwolić Czad z obcych wpływów, niwelując fakt, że sam współpracował z państwem ościennym (Jakubowski, 1987, s. 14; Urbaniak, 1983, s. 6).

Jednak powyższego stanowiska nie można rozciągać na całość polskiej publicystyki tego okresu, poświęconej zagadnieniu wojny w Czadzie. Dostrzec można analityczne artykuły, w których zwraca się uwagę na złożoność problemów tego państwa. Przyczyn wojny doszukiwano się w kolonialnej przeszłości tego wielowyznaniowego i wieloetnicznego państwa o sztucznych granicach. Tragiczna sytuacja ekonomiczna była niejako determinantem, popychającym wielu mieszkańców Czadu do wzajemnych walk. Zwracano wówczas uwagę, że interwencje - czy to francuska, czy libijska - nie są kluczowymi problemami wobec powyższych trudności. W tych publikacjach odczuć można silny pesymizm co do przyszłości tego kraju, połączony z brakiem choćby mglistych pomysłów na zmianę tej sytuacji (Krasicki, 1978, s. 6; Kieniewicz, 1981, s. 11; Kamiński, 1987b, s. 5; Jakubowski, 1980, s. 14). W podobnym tonie utrzymany był wywiad z członkiem FROLINAT Abba Sidikiem, który przeprowadził w 1971 r. korespondent „Życia Warszawy" Tadeusz Jackowski (Jackowski, 1971, s. 6).

Niestabilna sytuacja w Czadzie przyczyniła się do postępów wojsk wiernych H. Habréemu, który pod koniec 1981 r. odzyskał Abéché oraz Faya-Largeau, a 7.06 .1982 r. stolicę - Ndżamenę (Angoyo, 1986, s. 103). W swych działaniach wspierany był przez Arabię Saudyjską, USA, Francję i Sudan, mimo że jeszcze w styczniu 1982 r. G. Oueddei udał się do Chartumu w celu uregulowania wzajemnych stosunków. Siły IAF zachowały w tym czasie bierność. Obalony G. Oueddei uciekł do Kamerunu, a następnie udał się na emigrację do Libii (Gérard, 1984, s. 119; Soska, 2008, s. 6; Arabia Saudyjska popiera rebeliantów w Czadzie, 1982, 6, s. 60-61; Pasierbiński, 1982, s. 6; Sożewska, 1983, s. 10).

Były prezydent w miejscowości Bardaï, w zachodniej części Strefy Aouzou, przystąpił do odtwarzania swoich wojsk, a następnie kontrofensywy na teryto- 
ria kontrolowane przez H. Habréa. Dzięki libijskiej pomocy G. Oueddei zdobył w czerwcu 1983 r. Faya-Largeau, a 8 lipca zajął Abéché, odcinając tym samym H. Habréa od zaopatrzenia z Sudanu (Maszek, 1983, s. 12). W obliczu zagrożenia nowy prezydent zwrócił się o pomoc za granicę. Francuzi obiecali mu wsparcie powietrzne, Zair wysłał 2 tys. żołnierzy do zabezpieczenia Ndżameny, a USA przekazały uzbrojenia za sumę $25 \mathrm{mln} \$$. Dzięki temu wsparciu H. Habré odzyskał utracone obszary jeszcze 30 lipca (Tartter, 1989, s. 250).

W obliczu klęsk ponoszonych przez G. Oueddeiego Libia zdecydowała się zintensyfikować dlań pomoc. Oprócz nalotów myśliwskich M. Kaddafi wysłał do wsparcia byłego prezydenta 4-5 tys. żołnierzy, wraz z czołgami, transporterami opancerzonymi i ciężką artylerią. W odpowiedzi Francja, w ramach operacji „Manta”, zwiększyła liczebnie swoje siły powietrzne zlokalizowane w stolicy Czadu oraz wysłała jednostki Legii Cudzoziemskiej. Całość sił francuskich szacowano na 3,5 tys. ludzi (Tartter, 1990, s. 193-194; Moszumański, 2007, s. 119).

Obecność obcych wojsk w Czadzie doprowadziła de facto do podziału kraju wzdłuż 16 równoleżnika, który nazywany był „czerwoną linią”. Część północna była kontrolowana przez Libię, natomiast południowa przez Francję. We wrześniu 1984 r. oba kraje doszły do porozumienia, zakładając jednoczesne wycofanie swoich wojsk z Czadu w terminie dwóch miesięcy (Le problème tchadien. Rappel historique, 1984, s. 14; Jabłonowski, 1988, s. 10). Umowa jednak nie była przestrzegana przez Libię, która pozostawiła przynajmniej 3 tys. swoich żołnierzy w północnych rejonach prefektury Borkou-Ennedi-Tibesti (Zeidan, 1989, s. 225). Czasowe wstrzymanie działań wojennych nie poprawiło losu ludności cywilnej, której w samym tylko grudniu 1984 r. wyjechało aż 13 tys. do Republiki Środkowoafrykańskiej (Brandily, 1984, s. 65).

Wszyscy obserwatorzy sytuacji wewnątrz Czadu byli przekonani, że powyższe posunięcia są tylko czasowe i nie doprowadzą do zakończenia długotrwałego konfliktu. Decyzje polityczne nie rozwiązywały bowiem źródeł wojny domowej, które tkwiły w różnorodności etnicznej i religijnej oraz osobistych ambicjach lokalnych przywódców. Istotnym czynnikiem była również ingerencja państw obcych w wewnętrzne sprawy Czadu. Ośrodki te nie zamierzały zrezygnować ze swych wpływów w tym państwie, a to doprowadziło do ostatniej fazy konfliktu, jakim była tzw. wojna Toyot w latach 1986-19875.

${ }^{5}$ Problem ten oraz jego wydźwięk w dyplomacji polskiej zostanie omówiony w osobnym artykule. 


\section{Bibliografia:}

Angoyo, P. (1986). W pierwszych szeregach bojowników. Problemy Pokoju i Socjalizmu, 7. Arabia Saudyjska popiera rebeliantów w Czadzie. (1982). As Sadaka, 6.

Berry, L. (1989). Independent Libya. W: Libya. A Country Study. Washington: United States Government Printing Office.

Brandily, M. (1984). Le Tchad face nord 1978-1979. Politique Africaine, 16.

Budrewicz, O. (1974). Pasem głodu i śmierci. Zagubieni w Czadzie. Perspektywy, 49.

Budrewicz, O. (1977). Ta przeklęta susza. Warszawa: Iskry.

Buijtenhuijs, R. (1981). Guerre de Guerilla et révolution en Afrique Noire. Les Leçons du Tchad. Politique Africaine, 1.

Byrnes, R.M. (1990). Foreign Relations. W: Chad. A Country Study. Washington: United States Government Printing Office.

Collier, J.L. (1990a). Tombalbaye Era 1960-75. W: Chad. A Country Study. Washington: United States Government Printing Office.

Collier, J.L. (1990b). Civil War and Northern Dominance, 1975-82. W: Chad. A Country Study. Washington: United States Government Printing Office.

Czekała-Mucha, G. (1979). Sprawa Françoise Claustre. Warszawa: Krajowa Agencja Wydawnicza.

Dembiński, L. (1974). Klęska na pustyni. Tygodnik Powszechny, 22.

Gérard, A. (1984). Nimeiry face aux crises tchadiennes. Politique Africaine, 16.

Jabłonowski, H. (1988). Awantura na pustyni. Przeglad Tygodniowy, 6.

Jackowski, T. (1970). Wojna domowa w Republice Czad. Życie Warszawy, 180.

Jackowski, T. (1971). Niepokoje w Czadzie. Życie Warszawy, 219.

Jakubowski, A. (1980). Konflikt na pustyni. Prawo i Życie, 18.

Jakubowski, A. (1987). Czad - splot cudzych interesów. Tygodnik Polski, 8.

Janicki, W. (1975). Liczy się jedno życie. Kierunki, 39.

Jedna Dżamahirijja? (1981). Polityka, 4.

Kalabiński, J. (1980). Na śmietniku imperium. Czad. Polityka, 15.

Kamiński, Z. (1979). Wojna w Czadzie. Życie Warszawy, 55.

Kamiński, Z. (1986). Czad. Wojna „starych lwów”. Życie Warszawy, 74.

Kamiński, Z. (1987a). Czad: 20 lat konfliktu. Bitwa o Auzu. Życie Warszawy, 190.

Kamiński, Z. (1987b). Wojna w sercu Afryki. Czad. Życie Warszawy, 7.

Katastrofalne skutki suszy w Afryce. (1973). Trybuna Ludu, 179.

Kieniewicz, J. (1981). Realizacja marzeń. Literatura, 5.

Kostecki, W. (1971). Nieznana wojna. Republika Czad. Perspektywy, 18.

Krasicki, I. (1978). Konflikt - i co dalej? Czad. Trybuna Ludu, 197.

Le problème tchadien. Rappel historique. (1984). Politique Africaine, 16.

Lubowski, A. (1975). Więzień pustyni Tibesti. Życie Gospodarcze, 51/52.

Łętocha, T. (1970). Polityka zagraniczna państw afrykańskich. Zbiór dokumentów. Warszawa: Polski Instytut Spraw Międzynarodowych.

Maszek, M. (1983). Znowu wojna. Czad. Polityka, 31.

Moszumański, P. (2007). Wojna domowa w Czadzie (1965-1990). Kwartalnik Bellona, $1(1)$. 
Pasierbiński, T. (1969). Czad. Legia znowu w akcji, Polityka, 50.

Pasierbiński, T. (1982). Więcej kłopotów niż spokoju. Czad. Trybuna Ludu, 270.

Pledge, R. (1970). Republika Czad, czyli francuska teoria afrykańskiego domina. Zeszyty Teoretyczno-Polityczne, 5.

Pogodowski, M. (1982). Zobowiązanie dotrzymane. As Sadaka, 1/2.

Radajewicz, A. (1982). Kto zawiódł przywódcę Czadu? As Sadaka, 4.

Rapacki, M. (1978). Wojna już zapomniana. Czad. Tygodnik Demokratyczny, 21.

Soska, M. (2008). Czad. 40 lat wojny o ropę i religię. Myśl Polska, 9.

Sożewska, M. (1983). Powracająca fala wojny. Tygodnik Demokratyczny, 34.

Tartter, J.R. (1989). International Military Concerns and Objectives. W: Libya. A Country Study. Washington: United States Government Printing Office.

Tartter, J.R. (1990). Civil Conflict and Libyan Intervention. W: Chad. A Country Study. Washington: United States Government Printing Office.

Urbaniak, J. (1983). Imperialistyczne źródła. Wojna w Czadzie. Trybuna Ludu, 176.

Zeidan, S.S. (1989). Foreign relations. W: Libya. A Country Study. Washington: United States Government Printing Office. 